\title{
Would you want to know? Public attitudes on early diagnostic testing for Alzheimer's disease
}

\author{
Elizabeth M Wikler ${ }^{1 *}$, Robert J Blendon² and John M Benson²
}

\begin{abstract}
Introduction: Research is underway to develop an early medical test for Alzheimer's disease (AD).

Methods: To evaluate potential demand for such a test, we conducted a cross-sectional telephone survey of 2,678 randomly selected adults across the United States and four European countries.

Results: Most surveyed adults (67\%) reported that they are "somewhat" or "very likely" to get an early medical test if one becomes available in the future. Interest was higher among those worried about developing AD, those with an immediate blood relative with $A D$, and those who have served as caregivers for AD patients. Older respondents and those living in Spain and Poland also exhibited greater interest in testing. Knowing AD is a fatal condition did not influence demand for testing, except among those with an immediate blood relative with the disease.

Conclusions: Potential demand for early medical testing for AD could be high. A predictive test could not only advance medical research, it could transform political and legal landscapes by creating a large constituency of asymptomatic, diagnosed adults.
\end{abstract}

Keywords: Alzheimer's disease, medical testing, predictive testing, medical decision-making, public attitudes, preclinical

\section{Introduction}

In 2011, an international team of experts revised the diagnostic criteria and guidelines used to identify Alzheimer's disease (AD). In recognition of recent scientific discoveries, the group proposed a research agenda focused on early detection of $\mathrm{AD}$, particularly when the disease is in a preclinical stage: after key biological changes have started to occur in the brain, but before the onset of noticeable symptoms [1]. Their hope was that identifying the disease in this preclinical stage will facilitate the development of new treatments to slow or halt the progression of the disease [2]. Across the globe, research on the predictive value of early medical tests used to detect Alzheimer's disease during this preclinical phase is underway, and is showing promising results $[3,4]$.

Although nascent, efforts to create an early medical test for Alzheimer's disease using both genetic information

\footnotetext{
* Correspondence: bethwikler@post.harvard.edu

'Harvard Graduate School of Arts and Sciences, 14 Story Street, 4th Floor, Cambridge, MA 02138 USA

Full list of author information is available at the end of the article
}

and disease biomarkers are gaining traction and, in the future, may be available for broad populations of asymptomatic patients outside of the research environment. While this could result in tremendous breakthroughs regarding treatment technologies, it raises practical, ethi$\mathrm{cal}$ and financial questions for individuals and communities across the globe. Most of all, people all over the world will face a decision: should they get tested? Would they want to know whether they will get this fatal, untreatable disease?

This paper draws on public opinion data from four Western European countries and the United States to assess potential international demand for early diagnostic testing for Alzheimer's disease. We also explore some of the factors associated with high and low levels of interest in early medical testing for $\mathrm{AD}$, employing constructs from the Health Belief Model, a commonly used theoretical model that predicts utilization of health services [5]. Our results suggest that demand for Alzheimer's testing among asymptomatic patients could be high across all five countries, particularly among those who perceive themselves to be at high risk for the disease.

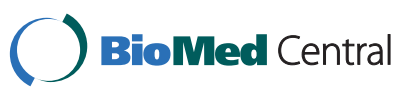

() 2013 Wikler et al.; licensee BioMed Central Ltd. This is an open access article distributed under the terms of the Creative Commons Attribution License (http://creativecommons.org/licenses/by/2.0), which permits unrestricted use, distribution, and reproduction in any medium, provided the original work is properly cited. 


\section{Early medical testing for $A D$}

For decades, scientists have been working to develop a reliable, predictive test for Alzheimer's disease. In 1994, genetic testing for late-onset Alzheimer's disease became available primarily in research settings, offering patients a probabilistic measure of their risk for the disease by analyzing their apolipoprotein $\mathrm{E}$ (ApoE) genotype. Individuals with two ApoE $\varepsilon 4$ alleles have more than seven times increased risk of developing AD than those with the ApoE $\varepsilon 3$ allele [6]. However, the ApoE $\varepsilon 4$ allele is neither a necessary nor sufficient predictor of the disease, and the association between ApoE $\varepsilon 4$ allele and $\mathrm{AD}$ has been shown to vary by race and ethnicity [7]. For these reasons and others - including the test's low sensitivity and specificity, the difficulty of interpreting probabilistic results, and the lack of prevention options - experts have largely opposed widespread clinical adoption of this genetic test [8].

Other initiatives have focused on disease biomarkers particularly those measuring changes in amyloid beta accumulation, synaptic and neuronal function, and brain structure - in hopes of developing tests that can track pathophysiological changes related to the development of the disease [9-13]. If these new tests can more accurately predict the onset of Alzheimer's disease, it is feasible that at some point in the future, they could be incorporated into a broader set of tests used for the early detection and diagnosis of Alzheimer's disease and made available to patients outside research settings.

\section{Health belief model}

In this paper, we drew on the Health Belief Model (HBM) to develop our hypotheses about the social and demographic factors that predict interest in $\mathrm{AD}$ testing. The HBM is a theoretical framework developed by the U.S. Public Health Service to help explain low participation rates in disease prevention programs $[5,14,15]$. The core premise of the model is that health behaviors, such as testing, are driven by personal beliefs about health conditions, for example, the extent to which a person feels threatened by a particular health condition, and the costs and benefits of the strategies available for its detection and treatment [14]. Individuals assess threat based on their perceptions of how susceptible they are to an illness and the severity of the illness, including its impact on their future [16]. In this study, we expected that measures of perceived risk would positively predict interest in testing, whereas measures of disease severity, including knowing the disease was fatal, would inversely predict interest [17-19]. Previous work also suggests that perceived benefits, such as enhanced planning and decision-making abilities around future care options, predict interest in testing, whereas perceived costs, such as lack of treatment, depress interest and uptake [20-22].

\section{Methods}

\section{Survey data and study participants}

The data for this paper come from an international telephone survey with a randomly-selected sample of 2,678 adult respondents age 18 and older, drawn from five countries: France, Germany, Poland, Spain and the United States. The Harvard School of Public Health and Alzheimer Europe commissioned the survey to assess public understanding about Alzheimer's disease. The fieldwork was conducted from 7 to 27 February 2011 by TNS which is one of the largest, independent research companies in the world and is based in London with branches in each of the five countries surveyed. In each of the five countries, interviews were conducted both by landline telephone using random-digit dialing and by cell phone using numbers chosen randomly from a list of cell phone numbers across the country. Interviews were conducted in the language of each country. In the United States, interviews were conducted in both English and Spanish. The average length of an interview was 12 minutes [23].

The survey, which has been described elsewhere, focused on eight broad topics, ranging from levels of public concern about the disease to public beliefs about whether an effective treatment is available to slow the progression of the disease [23]. In this analysis, we focused on results related to interest in future early diagnostic testing for the disease, should such a test become available.

In December 2010, the Institutional Review Board at the Harvard School of Public Health ruled that this study was not human subject research (Protocol \#19950-101).

Informed consent was obtained in the following manner. The interviewer told potential respondents that the call was being made on behalf of the Harvard School of Public Health. They were also told that the information they provided would remain confidential and be used for research purposes only. Potential respondents were not pressured into responding, and could have chosen not to be interviewed. Personal identifiers such as telephone numbers were discarded.

\section{Statistical analyses}

Nonresponse in telephone surveys produces some known biases in survey-derived estimates, because participation tends to vary for different subgroups of the population. To compensate for these biases, the sample data were weighted to reflect the actual composition of the adult population in the surveyed countries, calculated on the basis of census data from each country, according to age, gender and region. The sample data were also weighted by telephone status (landline, cell). Other techniques, such a selection within households, were used to help ensure that the sample in each country was representative. 
We used chi-squared tests (assessed at the conventional alpha level of 0.05 ) to evaluate the association between interest in testing and levels of perceived threat, perceived costs and benefits, and social and demographic factors. We then used regression analysis to analyze variables that predicted interest, adjusting for social and demographic factors. Only the final models are shown. As recommended by Strecher and Rosenstock, we did not aggregate items measuring the constructs of the health belief model, despite some measures being moderately interrelated, and instead, evaluated the impact of each measure separately [24]. However, we tested for potential interactions among these variables. As robustness checks, we ran country-specific regression models, and evaluated all models using probit regression.

Our main outcome variable - interest in testing - was derived from the following survey question: "[i]n the future, a medical test might become available that would tell people before they had symptoms whether they will get Alzheimer's disease in the future. If such a test became available, how likely do you think it is that you would get the test - very likely, somewhat likely, not too likely, or not at all likely?" Because studies of genetic testing for other diseases have found that actual take-up rates tend to be lower than rates of expressed interest once tests become available, we focused our analyses on respondents who reported that they are "very likely" to get tested (1, very likely; 0, somewhat/not too/not at all likely) [21]. In additional analyses, we evaluated predictors of being "not at all likely" to get tested, creating a separate dichotomous outcome variable (1, not at all likely; 0 , very likely/somewhat/ not too). We dropped the "Don't know/Refused" respondents $(n=53)$ from this analysis.

The independent variables in this analysis were drawn from the Health Belief model [5,14]. Measures were broken into categories that evaluate levels of perceived threat and perceived costs and benefits of testing; demographic and psychological variables were also included in the models. Given differences in educational systems across the countries, we divided respondents into three categories: low, middle and high educational attainment. Across all countries, low education captured respondents who completed primary and some secondary schooling; middle education captured respondents who had completed high school and potentially some college; and high education referred to respondents with a college or post-university degree. Race and ethnicity data were collected only in the United States, so models evaluating their impact were conducted only for respondents living in that country. Respondents were broken down into the following categories: white (non-Hispanic), black (non-Hispanic), Hispanic, other (non-Hispanic). The other racial category included respondents who identified as Asian, Pacific Islander, Native American or other.
Reference categories for dichotomous variables were set at zero, and for categorical variables, they were set as the first group. All analyses were conducted using Stata 11 software, which was generated by StataCorp LP, a company located in College Station, Texas in the United States.

\section{Results}

Table 1 shows unadjusted, weighted statistics on the relationship between interest in testing and our independent variables for respondents who expressed they would be "very likely" to take a medical test for AD.

\section{Bivariate analyses}

Overall, we found that more than two-thirds of respondents across all countries would be "very likely" (30\%) or "somewhat likely" (37\%) to obtain an early medical test if it were available in the future; $21.1 \%$ would be "not too likely," and $11.9 \%$ would be "not at all likely" to pursue testing. Individuals who reported high levels of perceived threat, across a range of measures, were more likely to indicate that they are "very likely" to undergo testing $[15,17,25,26]$. For example, we found that $35.3 \%$ of respondents who had an immediate blood relative with AD report that they were "very likely" to get tested as compared to $27.8 \%$ without an affected relative. Similar patterns emerged for those who served as a caretaker or decision-maker (40.4\% versus $27.9 \%$ ), for those who were "very" or "somewhat" worried about getting AD (38.1\% versus $23.5 \%$ ), and for those who were in "fair" or "poor" health (34\% versus $28.9 \%$ ). Unexpectedly, knowing that $\mathrm{AD}$ is a fatal condition - a measure of perceived disease severity - had no statistically significant relationship to interest in testing.

Only one of our measures of perceived costs and benefits was associated with interest in testing: those who expected to rely on a paid caregiver if they developed $\mathrm{AD}$, as opposed to a spouse, child, friend or other, were more likely to desire testing (33.4\% versus $28.6 \%$ ).

Our analysis showed that all of the demographic and psychological control variables in our model were statistically significantly related to being "very likely" to pursue testing. Older populations - those aged 50 and above reported more often than younger populations that they were "very likely" to get an early AD test (for example, $38.9 \%$ for 65 to 74 year olds versus $25.3 \%$ for 18 to 29 year olds); women were more interested than men $(32.2 \%$ versus $27.7 \%$ ); and those with the lowest levels of education were more interested than those with the highest (32.4\% versus 25.9\%). Country-level differences were also particularly striking - Spain and Poland had the highest shares of respondents reporting that they were "very likely" to pursue testing (39.6\% and 30.5\%) and Germany the lowest (23.6\%). 
Table 1 Characteristics of total sample and subpopulations who are "very likely" to obtain preclinical AD test

\begin{tabular}{|c|c|c|c|c|}
\hline \multirow{2}{*}{ Entire sample } & \multicolumn{2}{|c|}{ Entire sample } & \multicolumn{2}{|c|}{ Very likely to get early medical test for $A D$} \\
\hline & & & $30.0 \%$ & [28.1 to 31.9$]$ \\
\hline \multicolumn{5}{|l|}{ Have/had immediate blood relative with $A D$} \\
\hline No & $77.1 \%$ & [75.2 to 79.0$]$ & $27.8 \% * * *$ & [25.7 to 30.1$]$ \\
\hline Yes & $22.9 \%$ & [21.0 to 24.8$]$ & $35.3 \%$ & [31.2 to 39.7$]$ \\
\hline \multicolumn{5}{|l|}{ Served as decision-maker or caretaker for AD patient } \\
\hline No & $83.0 \%$ & [81.4 to 84.7$]$ & $27.9 \% *$ & [25.8 to 30.0] \\
\hline Yes & $17.0 \%$ & [15.3 to 18.6$]$ & $40.4 \%$ & [35.6 to 45.5$]$ \\
\hline \multicolumn{5}{|l|}{ Worried will get Alzheimer's disease } \\
\hline Not too/not at all/don't know/refused & $55.3 \%$ & [53.1 to 57.5$]$ & $23.5 \% * *$ & [21.2 to 26.0] \\
\hline Very/somewhat worried & $44.7 \%$ & {$[42.5$ to 46.9$]$} & $38.1 \%$ & [35.1 to 41.2$]$ \\
\hline \multicolumn{5}{|l|}{ Health status } \\
\hline Fair/poor & $20.3 \%$ & [18.5 to 22.2] & $34 \%^{*}$ & [29.8 to 38.4$]$ \\
\hline Excellent/very good/good & $79.7 \%$ & [77.8 to 81.5$]$ & $28.9 \%$ & [26.8 to 31.1$]$ \\
\hline \multicolumn{5}{|l|}{ Think AD is fatal } \\
\hline No/Don't know/refused & $55.5 \%$ & [53.3 to 57.7$]$ & $28.9 \%$ & [26.4 to 31.5$]$ \\
\hline Yes & $44.5 \%$ & [42.3 to 46.7$]$ & $31.4 \%$ & [28.6 to 34.4$]$ \\
\hline \multicolumn{5}{|l|}{ Marital status } \\
\hline No & $46.3 \%$ & [44.1 to 48.6$]$ & $28.9 \%$ & [26.1 to 31.9] \\
\hline Yes & $53.7 \%$ & [51.4 to 55.9$]$ & $30.9 \%$ & [28.4 to 33.6$]$ \\
\hline \multicolumn{5}{|l|}{ Expect paid caregiver to be primary caretaker if develop $A D$} \\
\hline No & $70.8 \%$ & [68.7 to 72.8$]$ & $28.6 \% *$ & [26.3 to 30.9] \\
\hline Yes & $29.2 \%$ & {$[27.2$ to 31.3$]$} & $33.4 \%$ & [29.8 to 37.2$]$ \\
\hline \multicolumn{5}{|c|}{ Believe an effective AD treatment is available now or will be in five years } \\
\hline No/don't know/refused & $32.1 \%$ & [30.0 to 34.2] & $28.5 \%$ & [25.3 to 32.0] \\
\hline Yes & $67.9 \%$ & [65.8 to 70.0$]$ & $30.8 \%$ & [28.4 to 33.2$]$ \\
\hline \multicolumn{5}{|l|}{ Age } \\
\hline 18 to 29 & $23.7 \%$ & [21.7 to 25.8$]$ & $25.3 \% \%^{* *}$ & [21.3 to 29.9] \\
\hline 30 to 49 & $37.2 \%$ & [35.1 to 39.4$]$ & $25.1 \%$ & [22.2 to 28.2$]$ \\
\hline 50 to 64 & $21.6 \%$ & [19.9 to 23.3] & $36.9 \%$ & [33.1 to 40.9] \\
\hline 65 to 74 & $11.6 \%$ & [10.2 to 13.0$]$ & $38.9 \%$ & [33.2 to 45.0$]$ \\
\hline 75 to $85+$ & $5.9 \%$ & [4.9 to 6.9$]$ & $34.3 \%$ & [27.0 to 42.3$]$ \\
\hline \multicolumn{5}{|l|}{ Gender } \\
\hline Male & $48.2 \%$ & [46.0 to 50.5$]$ & $27.7 \%^{*}$ & [24.9 to 30.5$]$ \\
\hline Female & $51.8 \%$ & [49.5 to 54.0$]$ & $32.2 \%$ & [29.6 to 34.9$]$ \\
\hline \multicolumn{5}{|l|}{ Educational attainment } \\
\hline Low & $32.5 \%$ & [30.4 to 34.6$]$ & $32.4 \% *$ & [29.0 to 35.9$]$ \\
\hline Middle & $30.2 \%$ & [28.1 to 32.3$]$ & $32.1 \%$ & [28.6 to 35.9$]$ \\
\hline High & $37.3 \%$ & [35.1 to 39.5$]$ & $25.9 \%$ & [23.0 to 29.0] \\
\hline \multicolumn{5}{|l|}{ Country } \\
\hline France & $20.8 \%$ & [19.0 to 22.6] & $26.8 \% * * *$ & [22.9 to 31.2$]$ \\
\hline Germany & $17.9 \%$ & [16.2 to 19.7$]$ & $23.6 \%$ & [19.7 to 28.0] \\
\hline Poland & $17.8 \%$ & [16.1 to 19.5$]$ & $30.5 \%$ & [26.2 to 35.2$]$ \\
\hline Spain & $18.4 \%$ & [16.6 to 20.1$]$ & $39.6 \%$ & [34.9 to 44.4$]$ \\
\hline United States & $25.1 \%$ & [23.1 to 27.0$]$ & $29.7 \%$ & [26.0 to 33.7] \\
\hline \multicolumn{5}{|l|}{ Race (U.S. Only, N = 639) } \\
\hline White & $68.3 \%$ & [64.3 to 72.4$]$ & $25.3 \%$ & to 30.0$]$ \\
\hline Black & $11.6 \%$ & [9.1 to 13.9] & $45.1 \%$ & to 56.0$]$ \\
\hline Hispanic & $14.1 \%$ & [11.3 to 16.9$]$ & $34.7 \%$ & to 44.8$]$ \\
\hline Other (Asian, Pacific Islander, Native American, Other) & $6.1 \%$ & {$[3.1$ to 8.9$]$} & $39.1 \%$ & to 65.2$]$ \\
\hline \multicolumn{5}{|l|}{ Would see doctor if showing symptoms of $A D$} \\
\hline No & $9.2 \%$ & {$[7.8$ to 10.5$]$} & $19 \% * *$ & [13.3 to 26.6$]$ \\
\hline Yes & $90.8 \%$ & [89.5 to 92.2$]$ & $31.4 \%$ & [29.4 to 33.5$]$ \\
\hline
\end{tabular}

$N=2,678 ;{ }^{*} P<.05 ;{ }^{* * P}<.01 ;{ }^{* * *} P<.001$ using chi-square tests of differences between expected and observed distributions. Sample sizes vary across categories due to missing data. Confidence intervals in brackets. 
Lastly, we found that those with potentially stronger coping abilities, as captured by their more active information-seeking style (measured by asking respondents if they would see a doctor if showing symptoms of AD) were more likely to express interest in testing (31.4\% versus 19\%) [27].

In the United States, whites were less likely than blacks and Hispanics to respond that they would be "very likely" to get an early medical test for AD (25.3\% compared to $45.1 \%$ and $34.6 \%$, respectively). However, only the difference between whites and blacks was statistically significant.

We tested variables associated with being "not at all likely" to get an early medical test, and found that results largely mirrored those outlined above with one additional finding: those who believed there was a treatment for $\mathrm{AD}$, or that one will become available in the next five years, were less likely to respond that they were "not at all likely" to get tested (10.5\% versus $14.1 \%)$. This suggested that while treatment optimism may not motivate people to express strong interest in testing, it did prevent people from ruling out testing altogether.

Nevertheless, measures of perceived risk and perceived costs and benefits were interrelated. For example, women and caretakers were more likely to report being worried about getting AD, and having a close blood relative with $\mathrm{AD}$ was positively associated with higher levels of treatment optimism. To disentangle these effects, we used multivariate logistic regression to adjust for these correlations and check for potential interactive effects.

\section{Regression results}

Our logistic regression models evaluated interest in testing, adjusting for measures of perceived risk, measures of perceived costs and benefits, and demographic and social controls. Table 2 displays our results. On average, after controlling for social and demographic factors, we find that $28.4 \%$ of survey respondents are "very likely" to get a hypothetical, early medical test for AD. Although several factors, including the cost of the test and methods of test administration, may reduce rates of actual take-up once and if an AD test is available, this level of interest is similar to the $25 \%$ take-up rates documented among first-degree relatives of $\mathrm{AD}$ patients who were part of disease registries and contacted to partake in a randomized clinical trial for a genetic testing for $\mathrm{AD}[28]$.

Measures of perceived risk were the strongest predictors of interest in testing. For example, holding all else constant, the odds of being "very likely" to pursue testing were $76 \%$ higher for those worried about developing AD than for those not worried. Expecting to rely on a paid caregiver, older age, and country of residence also remained positive, statistically significant predictors of being interested in early medical testing.

On its own, knowing the disease is fatal had no statistically significant effect on interest in testing $(\mathrm{OR}=$ 1.112, $P>0.05)$. However, among those who knew the disease is fatal, the predicted probability of expressing interest in testing was higher for those who have a blood relative with $\mathrm{AD}$ as opposed to those without (38.7\% versus $26.8 \%$ ). Moreover, although poor health status was predictive of interest in testing in bivariate analyses, it was the worried well who expressed higher levels of interest in our final model. Among those who were worried about AD, those in better health were more likely than those in worse health to desire testing (predicted probabilities of $36.3 \%$ versus $31.9 \%$ ).

These results varied little when we broke them down by country (Table 3 ). Caretakers, especially those in Poland, report higher interest in testing as opposed to those who have not served as a caretaker or decisionmaker for an AD patient $(\mathrm{OR}=2.717, P<0.001)$. Despite different social support systems, interest was also high in most countries among those who expected to rely on a paid caregiver. However, although marital status was not a significant predictor of testing in the aggregate, married respondents in the United States were less likely than single respondents to report a desire for the test $(\mathrm{OR}=0.641, P<0.05)$.

Table 4 shows that in the United States, race and ethnicity were also significant predictors of interest in AD testing. On average, blacks and Hispanics were more likely than whites to report an interest in testing. The predicted probability of pursuing an early medical test for $\mathrm{AD}$ for whites was $23.1 \%$, but it was nearly double that for blacks $(41.3 \%)$ and $35.3 \%$ for Hispanics. There were no significant differences between minority groups on rates of interest.

Lastly, we explored factors associated with being "not at all likely" to pursue early medical testing. Not surprisingly, having a positive information-seeking style, for example, respondent reporting that $\mathrm{s} /$ he would visit a physician if exhibiting symptoms of Alzheimer's, was inversely related to being "not at all" interested in testing $(\mathrm{OR}=0.534, P<0.01)$. This suggests that those who would avoid physician visits were also more likely to avoid early medical testing.

\section{Discussion}

This is the first large, international, randomized survey of public interest in potential early medical testing for AD. We find that two out of three respondents would be interested in obtaining a hypothetical early medical test for AD. These rates are similar to results found in a 2011 internet survey conducted in the United States 
Table 2 Logistic Regression results evaluating variables predictive of being "very likely" to obtain preclinical AD test

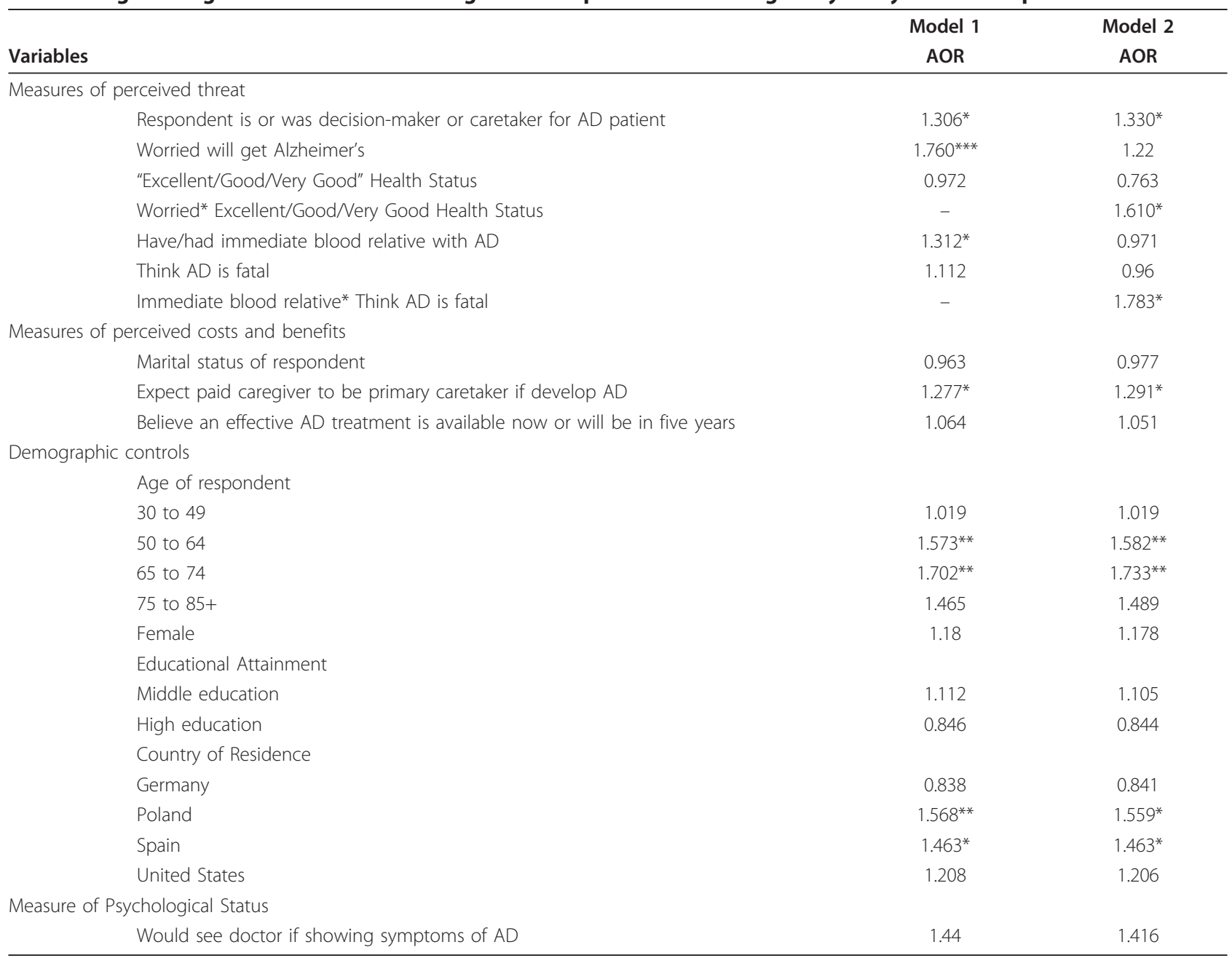

$\mathrm{AOR}=$ Adjusted odds ratio; reference groups, in order of the categories displayed in the table are: Ages 18 to 29 ; Low Education; France; ${ }^{*} P<0.05$, ${ }^{* *} P<0.01$, $* * * P<0.001$.

finding high levels of interest in and willingness to pay for $\mathrm{AD}$ testing (between $70 \%$ and $74.8 \%$ of respondents) [29]. In a study of first-degree relatives who had undergone APOE susceptibility testing, fear of developing the disease and a desire for information were among the chief predictors of willingness-to-pay [30].

These results suggest that demand will be highest among those who perceive themselves to be at risk for the disease, including those with a family history of AD, those worried about getting the disease, and those who serve as caregivers or decision-makers for $\mathrm{AD}$ patients $[17,19,25,26]$. Our study adds to the literature by uniquely showing the interactive nature of these measures. While in our bivariate analyses, those in worse health were more likely than healthy populations to desire testing, it was the worried well who expressed higher levels of interest in a hypothetical predictive test, controlling for demographic and social factors. While our own study does not directly ask about motivation for test-taking, studies of other late-onset disorders find that those with high levels of perceived risk view testing as a way of practically and emotionally coping with their worry, gaining control and getting clarity about their future $[15,31]$. Even in circumstances where no treatment options were available, study participants highlighted the non-medical benefits to test information, highlighting the "value of knowing" and the opportunity to change behaviors, such as getting follow-up care, spending time with family, and arranging their personal finances $[16,29]$.

Previous work on these survey data found that awareness of the disease's fatality was limited, ranging from $33 \%$ in Germany to $61 \%$ in the United States; however, awareness was higher among blood relatives of AD patients in France, Poland and Spain [23]. We hypothesized that interest in testing would be lower among 
Table 3 Country-level logistic regression results evaluating variables predictive of being "very likely" to obtain test

\begin{tabular}{|c|c|c|c|c|c|c|}
\hline Variable & $\begin{array}{l}\text { Entire } \\
\text { sample }\end{array}$ & France & Germany & Poland & Spain & $\begin{array}{l}\text { United } \\
\text { States }\end{array}$ \\
\hline \multicolumn{7}{|l|}{ Measures of perceived threat } \\
\hline Have/had immediate blood relative with $A D$ & $\begin{array}{l}1.312^{*} \\
(0.165)\end{array}$ & $1.194(0.336)$ & $\begin{array}{l}1.042 \\
(0.340)\end{array}$ & $\begin{array}{l}1.739 \\
(0.624)\end{array}$ & $\begin{array}{l}1.386 \\
(0.389)\end{array}$ & $\begin{array}{l}1.411 \\
(0.325)\end{array}$ \\
\hline $\begin{array}{l}\text { Respondent is or was decision-maker or caretaker for } A D \\
\text { patient }\end{array}$ & $\begin{array}{l}1.306^{*} \\
(0.175)\end{array}$ & $1.065(0.362)$ & $\begin{array}{l}0.973 \\
(0.363)\end{array}$ & $\begin{array}{l}2.717^{* *} \\
(0.977)\end{array}$ & $\begin{array}{l}1.170 \\
(0.307)\end{array}$ & $\begin{array}{l}1.066 \\
(0.288)\end{array}$ \\
\hline Worried will get Alzheimer's & $\begin{array}{l}1.760^{* * *} \\
(0.203)\end{array}$ & $\begin{array}{l}2.982^{* * *} \\
(0.755)\end{array}$ & $\begin{array}{l}1.647+ \\
(0.469)\end{array}$ & $\begin{array}{l}1.055 \\
(0.320)\end{array}$ & $\begin{array}{l}1.594 \\
(0.476)\end{array}$ & $\begin{array}{l}1.979^{* *} \\
(0.432)\end{array}$ \\
\hline Think AD is fatal & $1.112(0.117)$ & $1.332(0.302)$ & $\begin{array}{l}1.271 \\
(0.346)\end{array}$ & $\begin{array}{l}0.758 \\
(0.204)\end{array}$ & $\begin{array}{l}1.329 \\
(0.316)\end{array}$ & $\begin{array}{l}0.907 \\
(0.196)\end{array}$ \\
\hline "Excellent/Good/Very Good" health status & $0.972(0.125)$ & $0.814(0.261)$ & $\begin{array}{l}0.969 \\
(0.352)\end{array}$ & $\begin{array}{l}1.028 \\
(0.308)\end{array}$ & $\begin{array}{l}1.016 \\
(0.306)\end{array}$ & $\begin{array}{l}0.923 \\
(0.231)\end{array}$ \\
\hline \multicolumn{7}{|l|}{ Measures of perceived costs and benefits } \\
\hline Marital status of respondent & $0.963(0.113)$ & $1.445(0.397)$ & $\begin{array}{l}1.383 \\
(0.428)\end{array}$ & $\begin{array}{l}0.601 \\
(0.191)\end{array}$ & $\begin{array}{l}1.393 \\
(0.382)\end{array}$ & $\begin{array}{l}0.641^{*} \\
(0.142)\end{array}$ \\
\hline Expect paid caregiver to be primary caretaker if develop $A D$ & $\begin{array}{l}1.277^{*} \\
(0.146)\end{array}$ & $0.936(0.228)$ & $\begin{array}{l}1.991^{*} \\
(0.561)\end{array}$ & $\begin{array}{l}1.893+ \\
(0.650)\end{array}$ & $\begin{array}{l}1.359 \\
(0.327)\end{array}$ & $\begin{array}{l}1.001 \\
(0.224)\end{array}$ \\
\hline $\begin{array}{l}\text { Believe an effective AD treatment is available now or will be } \\
\text { in five years }\end{array}$ & $1.064(0.118)$ & $1.090(0.276)$ & $\begin{array}{l}0.920 \\
(0.251)\end{array}$ & $\begin{array}{l}1.196 \\
(0.339)\end{array}$ & $\begin{array}{l}1.057 \\
(0.242)\end{array}$ & $\begin{array}{l}1.173 \\
(0.277)\end{array}$ \\
\hline \multicolumn{7}{|l|}{ Age of respondent } \\
\hline 30 to 49 & $1.019(0.165)$ & $1.558(0.578)$ & $\begin{array}{l}2.491+ \\
(1.370)\end{array}$ & $\begin{array}{l}1.476 \\
(0.595)\end{array}$ & $\begin{array}{l}0.544+ \\
(0.189)\end{array}$ & $\begin{array}{l}0.677 \\
(0.221)\end{array}$ \\
\hline 50 to 64 & $\begin{array}{l}1.573^{* *} \\
(0.270)\end{array}$ & $1.291(0.563)$ & $\begin{array}{l}3.494^{*} \\
(2.077)\end{array}$ & $\begin{array}{l}3.649^{* *} \\
(1.529)\end{array}$ & $\begin{array}{l}0.827 \\
(0.329)\end{array}$ & $\begin{array}{l}1.291 \\
(0.417)\end{array}$ \\
\hline 65 to 74 & $\begin{array}{l}1.702^{* *} \\
(0.345)\end{array}$ & $\begin{array}{l}2.670^{*} \\
(1.241)\end{array}$ & $\begin{array}{l}2.762 \\
(1.887)\end{array}$ & $\begin{array}{l}2.865^{*} \\
(1.411)\end{array}$ & $\begin{array}{l}0.966 \\
(0.443)\end{array}$ & $\begin{array}{l}1.322 \\
(0.510)\end{array}$ \\
\hline 75 to $85+$ & $1.465(0.352)$ & $\begin{array}{l}3.191^{*} \\
(1.757)\end{array}$ & $\begin{array}{l}2.704 \\
(1.741)\end{array}$ & $\begin{array}{l}1.452 \\
(0.969)\end{array}$ & $\begin{array}{l}0.584 \\
(0.395)\end{array}$ & $\begin{array}{l}1.237 \\
(0.518)\end{array}$ \\
\hline \multicolumn{7}{|l|}{ Gender } \\
\hline Female & $1.180(0.123)$ & $1.035(0.241)$ & $\begin{array}{l}0.944 \\
(0.261)\end{array}$ & $\begin{array}{l}1.342 \\
(0.358)\end{array}$ & $\begin{array}{l}1.090 \\
(0.245)\end{array}$ & $\begin{array}{l}1.247 \\
(0.268)\end{array}$ \\
\hline \multicolumn{7}{|l|}{ Educational Attainment } \\
\hline Middle education & $1.112(0.144)$ & $0.882(0.270)$ & $\begin{array}{l}0.800 \\
(0.264)\end{array}$ & $\begin{array}{l}1.491 \\
(0.460)\end{array}$ & $\begin{array}{l}1.476 \\
(0.412)\end{array}$ & $\begin{array}{l}0.902 \\
(0.238)\end{array}$ \\
\hline High education & $0.846(0.109)$ & $0.853(0.261)$ & $\begin{array}{l}0.576+ \\
(0.182)\end{array}$ & $\begin{array}{l}0.813 \\
(0.267)\end{array}$ & $\begin{array}{l}0.976 \\
(0.279)\end{array}$ & $\begin{array}{l}0.943 \\
(0.236)\end{array}$ \\
\hline \multicolumn{7}{|l|}{ Country of Residence } \\
\hline Germany & $0.838(0.147)$ & & & & & \\
\hline Poland & $\begin{array}{l}1.568^{* *} \\
(0.271)\end{array}$ & & & & & \\
\hline Spain & $\begin{array}{l}1.463^{*} \\
(0.235)\end{array}$ & & & & & \\
\hline United States & $1.208(0.192)$ & & & & & \\
\hline \multicolumn{7}{|l|}{ Measure of Psychological Status } \\
\hline Would see doctor if showing symptoms of $A D$ & $1.440(0.341)$ & $0.903(0.407)$ & $\begin{array}{l}1.055 \\
(0.569)\end{array}$ & $\begin{array}{l}1.695 \\
(0.844)\end{array}$ & $\begin{array}{l}3.711+ \\
(2.857)\end{array}$ & $\begin{array}{l}1.398 \\
(0.631)\end{array}$ \\
\hline Observations & 2357 & 494 & 423 & 419 & 436 & 585 \\
\hline Wald test & 110.47 & 33.44 & 23.48 & 50.6 & 21.13 & 34.21 \\
\hline$P$-value & 0 & 0.007 & 0.102 & 0 & 0.174 & 0.005 \\
\hline
\end{tabular}

$+P<0.10,{ }^{*} P<0.05$, ${ }^{* *} P<0.01$, ${ }^{* * *} P<0.001$. Table displays adjusted odds ratios and standard errors in parentheses. Country-level sample sizes are reduced due to missing data. Reference groups, in order of the categories displayed in the table are: Ages 18 to 29; Low Education; France

those who knew the disease was fatal, and even more so among those who genetically had higher chances of developing the disease. Unexpectedly, this knowledge had no significant effect on interest, except, inversely so, among respondents with a blood relative with AD. As noted previously, these respondents may value information over uncertainty, even in the context of potentially negative results [29]. 
Table 4 Logistic regression results evaluating interest in preclinical AD test by race in the United States

\begin{tabular}{|c|c|c|c|}
\hline Variable & & US & Predicted probability \\
\hline \multicolumn{4}{|l|}{ Race } \\
\hline & White & $1.000(-)$ & $23.1 \%$ \\
\hline & African American & $2.391^{* *}(0.689)$ & $41.8 \%$ \\
\hline & Hispanic & $1.820^{*}(0.499)$ & $35.4 \%$ \\
\hline & Other (Asian, Native American, or Other) & $2.259(1.297)$ & $40.5 \%$ \\
\hline Observations & & 585 & \\
\hline
\end{tabular}

$+P<0.10,{ }^{*} P<0.05,{ }^{* *} P<0.01,{ }^{* * *} P<0.001$. Table displays adjusted odds ratios and standard errors in parentheses. White is the reference category. Sample size is reduced due to missing data. Model controls for measures of perceived threat, perceived costs and benefits, demographic controls, and measure of psychological status.

Nevertheless, it could be that rates of interest do not translate into rates of take-up once, and if, a definitive, predictive test becomes available in clinical settings [27]. Yet, we anticipate that high prevlance rates for $\mathrm{AD}$, coupled with its later age of onset and broader media presence, could bolster participation rates beyond those documented for other uncurable, untreatable conditions $[27,28]$.

Middle- to older-age populations who are both closer to the age of onset and more likely to serve as caretakers are also more likely to express interest in testing [28]. Looking forward, as global populations age and as more people gain experience with the disease, the demand for early medical AD testing could rise. We anticipate that this demand will vary by country, with potentially high levels of demand in Poland, where support systems for AD patients are more fragmented and thus planning for care falls to individuals, and Spain, where AD related media has been prevalent and informal care giving is more common [32]. Compounding these factors, we expect interest and utilization of early medical testing for AD across countries to be affected by variations in clinical practice, care resources, cultural norms, disease epidemiology, levels of disease awareness and public policy responses [33,34].

Lastly, compared to whites, blacks and Hispanics living in the United States expressed significantly more interest in predictive testing for AD. This was unexpected given that earlier studies of genetic testing for cystic fibrosis, hereditary breast and ovarian cancers, and Alzheimer's disease, found either no differences across racial groups or that whites were more likely to express interest in genetic testing, seek out genetic counseling, and undergo testing once available [18,35-38]. However, one national telephone survey conducted in 2000 found that AfricanAmerican and Latino adults, in comparison to whites, were more likely to express interest in genetic testing for untreatable conditions [39].

Previous surveys have found that African American and Hispanic populations had higher levels of treatment optimism, believing scientists were close to finding a cure and that a cure would be available during the study participant's lifetime; moreover, minorities were also more likely than whites to report lower levels of concern about developing AD, which could explain differences observed in our study $[35,40,41]$. However, we found no statistically significant differences across racial groups on our survey measures of treatment optimism or levels of perceived risk. More work is needed to understand how these beliefs and interest vary across racial groups, and the extent to which individual- and structural-level factors affect rates of take-up once and if testing becomes available $[39,42,43]$.

\section{Transforming medical and legal landscapes}

If an early diagnostic test is indeed developed and demand matches global interest, millions of people in each of the studied countries will become members of a new population and political advocacy group: asymptomatic adults living with a diagnosis of Alzheimer's disease. Consequently, policymakers and clinicians should expect significant changes in the utilization of medical and economic resources and address potential legal obstacles.

In the medical realm, diagnosed but asymptomatic individuals are likely to press for follow-up testing, ongoing medical monitoring, and medical management of potential complications associated with Alzheimer's disease [44]. Given the uncertainty around the disease's pathogenesis and treatment mechanisms, the clinical value of such tests is unclear, and these additional costs could strain already-overburdened health systems, making the tradeoffs involved in allocating medical resources even more difficult $[32,45]$. However, the non-clinical benefits of testing, such as signing advanced directives and spending more time with family and friends, do provide value and should be appropriately considered in cost-benefit calculations [46].

In the legal realm, early medical testing for $\mathrm{AD}$ raises challenging questions related to testing protocols, disclosure practices, confidentiality protections, employment and insurance discrimination, and the availability of follow-up care $[47,48]$. If not appropriately addressed, any of these issues could pose real barriers to test participation. For instance, insurers, including health, life, disability or 
long-term care insurers, may want access to private health information to protect against adverse selection. These desires are not unreasonable. In the United States, one study found that individuals who underwent genetic testing for Alzheimer's disease were five times more likely than those who were untested to change their long-term care insurance coverage in the year following testing [49]. Similar results were found among those who were found to be at risk for Huntington's disease [50].

The US and Europe have enacted a range of measures to protect individuals against employment and insurance discrimination on the basis of genetic information, such as the Genetic Information and Nondiscrimination Act of 2008 in the US and the 1999 Oviedo Convention of Human Rights and Biomedicine in Europe. However, research suggests that the laws protecting against genetic discrimination in Europe have had mixed results on providing adequate protections and have not always kept pace with scientific advancements [51].

Furthermore, if an early medical test were developed for Alzheimer's disease that did not involve genetic information, such as blood tests evaluating protein levels, it is unclear to what extent these anti-discrimination protections would apply to diagnosed individuals. Before introducing early medical testing for AD into clinical practice, government leaders will need to examine whether existing protections are sufficient for diagnosed individuals and how these protections affect the viability of voluntary private insurance markets.

\section{Limitations and opportunities for future work}

Future research could build on this analysis in a number of ways. First, imprecision in our survey question may introduce some bias in our results. For example, the phrase "in the future" is used twice: to describe both the potential existence of an early medical test for Alzheimer's, and to refer to the possibility that the respondent will get Alzheimer's disease later in life. Our results encapsulate respondents' beliefs about the timing and availability of such a test, their interest in the actual test, and their level of concern for events that may happen in the future. Although we control for beliefs about scientific advancement, levels of concern about getting Alzheimer's disease, and age in our models predicting interest, future surveys should consider introducing a hypothetical situation in which a test already exists.

Second, we do not include potentially relevant financial, social and emotional variables, such as the respondents' insurance status, willingness to pay for testing, test administration, family size, country-specific policies, AD media coverage, level of religiosity, history of depression or fear of discrimination [30,35,46,52,53]. Third, future surveys should measure whether people would want to take such a test if they were told that no treatment or cure is currently available. Fourth, while we implied that the test would be completely predictive, we did not explicitly state so. As has been done previously, future work could test whether respondents would want to take a test if it were partially or perfectly predictive $[25,46]$. Lastly, future analyses could enhance this work by including more questions about test motivations, perceived costs and benefits, and measures of psychological style, including the Miller Behavioral Style Scale $[22,54,55]$.

\section{Conclusions}

In summary, our survey indicates that across four European countries and the United States, interest in early medical testing for Alzheimer's disease is high. We expect those with high levels of perceived risk - those who are worried about getting AD as well as those with more experience with the disease, including caregivers and blood relatives of AD patients - will be among those most likely to pursue testing once it becomes available. While early detection could hasten the development of treatment protocols, high demand for testing and the creation of a large group of asymptomatic adults with an Alzheimer's diagnosis could have significant political, economic and legal implications, and could transform the way $\mathrm{AD}$ is addressed by countries in the future.

\section{Abbreviations}

AD: Alzheimer's disease; ApoE: apolipoprotein E; HBM: Health Belief Model.

\section{Competing interests}

The authors declare that they have no competing interests.

\section{Authors' contributions}

Each author contributed to the drafting of the manuscript and the interpretation of the data. EW conducted the analysis and drafted initial versions of this article. RB and JB made critical revisions in the article and took the lead in writing the survey used in this analysis. All authors approve of this published draft.

\section{Acknowledgements}

We would like to thank David Cutler and Richard Frank for their invaluable input on earlier drafts of this paper. The survey was supported by a grant to Alzheimer Europe from Bayer AG. Bayer was not involved in the design of the survey, the data collection, the analysis or interpretation of the findings, or the preparation of the manuscript.

\section{Authors' details}

${ }^{1}$ Harvard Graduate School of Arts and Sciences, 14 Story Street, 4th Floor, Cambridge, MA 02138 USA. ${ }^{2}$ Department of Health Policy and Management, 677 Huntington Avenue, Kresge Building, Room 402, Boston, MA 02115 USA.

Received: 5 February 2013 Revised: 17 June 2013

Accepted: 6 September 2013 Published: 6 September 2013

\section{References}

1. DeKosky ST, Carrillo MC, Phelps C, Knopman D, Petersen RC, Frank R, Schenk D, Masterman D, Siemers ER, Cedarbaum JM: Revision of the criteria for Alzheimer's disease: a symposium. Alzheimers Dement 2011, 7: e1-e12. 
2. Sperling RA, Aisen PS, Beckett LA, Bennett DA, Craft S, Fagan AM, Iwatsubo T, Jack CR, Kaye J, Montine TJ, Park DC, Reiman EM, Rowe CC, Siemers E, Stern Y, Yaffe K, Carrillo MC, Thies B, Morrison-Bogorad M, Wagster MV, Phelps CH: Toward defining the preclinical stages of Alzheimer's disease: Recommendations from the National Institute on Aging and the Alzheimer's Association workgroup. Alzheimers Dement 2011, 7:280-292.

3. Ballard C, Corbett A, Jones EL: Dementia: challenges and promising developments. Lancet Neurol 2011, 10:7-9.

4. Johnstone D, Milward EA, Berretta R, Moscato P, Alzheimer's Disease Neuroimaging Initiative: Multivariate protein signatures of pre-clinical Alzheimer's disease in the Alzheimer's disease neuroimaging initiative (ADNI) plasma proteome dataset. PLOS ONE 2012, 7:e34341.

5. Rosenstock I: Why people use health services. Milbank Mem Fund Q 2005, 83:1-32.

6. Ballard C, Gauthier S, Corbett A, Brayne C, Aarsland D, Jones E: Alzheimer's disease. Lancet 2011, 377:1019-1031.

7. Farrer LA, Cupples LA, Haines JL, Hyman B, Kukull WA, Mayeux R, Myers RH, Pericak-Vance MA, Risch N, van Duijn CM: Effects of age, sex, and ethnicity on the association between apolipoprotein $\mathrm{E}$ genotype and Alzheimer disease. A meta-analysis. JAMA 1997, 278:1349-1356.

8. Goldman JS, Hahn SE, Catania JW, Larusse-Eckert S, Butson MB, Rumbaugh M, Strecker MN, Roberts JS, Burke W, Mayeux R, Bird T: Genetic counseling and testing for Alzheimer disease: joint practice guidelines of the American College of Medical Genetics and the National Society of Genetic Counselors. Genet Med 2011, 13:597-605.

9. Harold D, Abraham R, Hollingworth P, Sims R, Gerrish A, Hamshere ML, Pahwa JS, Moskvina V, Dowzell K, Williams A, Jones N, Thomas C, Stretton A, Morgan AR, Lovestone S, Powell J, Proitsi P, Lupton MK, Brayne C, Rubinsztein DC, Gill M, Lawlor B, Lynch A, Morgan K, Brown KS, Passmore PA, Craig D, McGuinness B, Todd S, Holmes C, et al: Genomewide association study identifies variants at CLU and PICALM associated with Alzheimer's disease, and shows evidence for additional susceptibility genes. Nat Genet 2009, 41:1088-1093.

10. Seshadri S, Fitzpatrick AL, Ikram MA, DeStefano AL, Gudnason V, Boada M, Bis JC, Smith AV, Carassquillo MM, Lambert JC, Harold D, Schrijvers EM, Ramirez-Lorca R, Debette S, Longstreth WT Jr, Janssens AC, Pankratz VS, Dartigues JF, Hollingworth P, Aspelund T, Hernandez I, Beiser A, Kuller LH, Koudstaal PJ, Dickson DW, Tzourio C, Abraham R, Antunez C, Du Y, Rotter וر et al: Genome-wide analysis of genetic loci associated with Alzheimer's disease. JAMA 2010, 303:1832-1840.

11. Mattsson N, Blennow K, Zetterberg H: CSF biomarkers: pinpointing Alzheimer pathogenesis. Ann N Y Acad Sci 2009, 1180:28-35

12. Shaw LM, Vanderstichele H, Knapik-Czajka M, Clark CM, Aisen PS, Petersen RC, Blennow K, Soares H, Simon A, Lewczuk P, Dean R, Siemers E, Potter W, Lee VM, Trojanowski JQ, Alzheimer's Disease Neuroimaging Initiative: Cerebrospinal fluid biomarker signature in Alzheimer's disease neuroimaging initiative subjects. Ann Neurol 2009, 65:403-413.

13. Hampel H, Bürger K, Teipel SJ, Bokde AL, Zetterberg H, Blennow K: Core candidate neurochemical and imaging biomarkers of Alzheimer's disease. Alzheimers Dement 2008, 4:38-48.

14. Hochbaum GM: Public Participation in Medical Screening Programs: a Sociopsychological Study Washington, D.C.: Public Health Service, U.S. Government Printing Office; 1958, PHS 972.

15. Janz NK, Becker MH: The Health Belief Model: a decade later. Health Educ Q 1984, 11:1-47.

16. Gooding HC, Linnenbringer EL, Burack J, Roberts JS, Green RC, Biesecker BB: Genetic susceptibility testing for Alzheimer disease: motivation to obtain information and control as precursors to coping with increased risk. Patient Educ Couns 2006, 64:259-267.

17. Roberts JS: Anticipating response to predictive genetic testing for Alzheimer's disease: a survey of first-degree relatives. Gerontologist 2000, 40:43-52.

18. Green R, Clarke V, Thompson N, Woodard J, Letz R: Early detection of Alzheimer disease: methods, markers, and misgivings. Alzheimer Dis Assoc Disord 1997, 11(Suppl 5):S1-5, discussion S37-39.

19. Becker MH, Kaback MM, Rosenstock IM, Ruth MV: Some influences on public participation in a genetic screening program. J Community Health 1975, 1:3-14

20. Champion VL, Skinner CS: The Health Belief Model. In Health Behavior and Health Education: Theory, Research, and Practice.. 4 edition. Edited by: Glanz K, Rimer B, Viswanath K. San Francisco, CA: John Wiley 2008:45-65.
21. Quaid K, Morris M: Reluctance to undergo predictive testing: the case of Huntington disease. Am J Med Genet 1993, 45:41-45.

22. Christensen KD, Roberts JS, Uhlmann WR, Green RC: Changes to perceptions of the pros and cons of genetic susceptibility testing after APOE genotyping for Alzheimer disease risk. Genet Med 2011, 13:409-414.

23. Blendon RJ, Benson JM, Wikler EM, Weldon KJ, Georges J, Baumgart M, Kallmyer BA: The impact of experience with a family member with Alzheimer's disease on views about the disease across five countries. Int J Alzheimers Dis 2012, 2012:903645.

24. Strecher V, Rosenstock I: The Health Belief Model. In Cambridge Handbook of Psychology, Health and Medicine.. 1 edition. Edited by: Baum A, Newman S, Weinman J, West R, McManus C. Cambridge, UK: Cambridge University Press; 1997:113-116.

25. Neumann PJ, Hammitt JK, Mueller C, Fillit HM, Hill J, Tetteh NA, Kosik KS: Public attitudes about genetic testing for Alzheimer's disease. Health Aff (Millwood) 2001, 20:252-264.

26. Marteau TM, Croyle RT: The new genetics: psychological responses to genetic testing. BMJ 1998, 316:693-696.

27. Evers-Kiebooms G, Welkenhuysen M, Claes E, Decruyenaere M, Denayer L: The psychological complexity of predictive testing for late onset neurogenetic diseases and hereditary cancers: implications for multidisciplinary counselling and for genetic education. Soc Sci Med 2000, 51:831-841.

28. Roberts JS, Barber M, Brown TM, Cupples LA, Farrer LA, LaRusse SA, Post SG, Quaid KA, Ravdin LD, Relkin NR, Sadovnick AD, Whitehouse PJ, Woodard JL, Green RC: Who seeks genetic susceptibility testing for Alzheimer's disease? Findings from a multisite, randomized clinical trial. Genet Med 2004, 6:197-203.

29. Neumann PJ, Cohen JT, Hammitt JK, Concannon TW, Auerbach HR, Fang C, Kent D: Willingness-to-pay for predictive tests with no immediate treatment implications: a survey of US residents. Health Econ 2012, 21:238-251.

30. Kopits IM, Chen C, Roberts JS, UhImann W, Green RC: Willingness to pay for genetic testing for Alzheimer's disease: a measure of personal utility. Genet Test Mol Biomarkers 2011, 15:871-875.

31. Dudokdewit AC, Tibben A, Niermeijer MF: Psychological distress in applicants for predictive DNA testing for autosomal dominant, heritable, late onset disorders. J Med Genet 1997, 34:382-390.

32. Wimo A, Jönsson L, Gustavsson A, McDaid D, Ersek K, Georges J, Gulácsi L, Karpati $\mathrm{K}$, Kenigsberg $\mathrm{P}$, Valtonen $\mathrm{H}$ : The economic impact of dementia in Europe in 2008-cost estimates from the Eurocode project. Int J Geriatr Psychiatry 2011, 26:825-832.

33. Vas CJ, Rajkumar S, Tanyakitpisal P, Chandra V: Alzheimer's Disease: The Brain Killer: When Old Age Becomes A Disease New Delhi: WHO Regional Office for South-East Asia; 2001.

34. Meijers-Heijboer EJ, Verhoog LC, Brekelmans CT, Seynaeve C, TilanusLinthorst MM, Wagner A, Dukel L, Devilee P, van den Ouweland AM, van Geel AN, Klijn JG: Presymptomatic DNA testing and prophylactic surgery in families with a BRCA1 or BRCA2 mutation. Lancet 2000, 355:2015-2020.

35. Connell CM, Roberts JS, McLaughlin SJ, Carpenter BD: Black and white adult family members' attitudes toward a dementia diagnosis. J Am Geriatr Soc 2009, 57:1562-1568.

36. Peters N, Rose A, Armstrong K: The association between race and attitudes about predictive genetic testing. Cancer Epidemiol Biomarkers Prev 2004, 13:361-365.

37. Halbert $\mathrm{CH}$, Kessler L, Stopfer JE, Domchek S, Wileyto EP: Low rates of acceptance of BRCA1 and BRCA2 test results among African American women at increased risk for hereditary breast-ovarian cancer. Genet Med 2006, 8:576-582.

38. Tambor ES, Rimer BK, Strigo TS: Genetic testing for breast cancer susceptibility: awareness and interest among women in the general population. Am J Med Genet 1997, 68:43-49.

39. Singer $E$, Antonucci T, Van Hoewyk J: Racial and ethnic variations in knowledge and attitudes about genetic testing. Genet Test 2004, 8:31-43.

40. Akinleye I, Roberts JS, Royal CD, Linnenbringer E, Obisesan TO, Fasaye GA Green RC: Differences between African American and White research volunteers in their attitudes, beliefs and knowledge regarding genetic testing for Alzheimer's disease. J Genet Couns 2011, 20:650-659.

41. Connell C, Roberts JS: Public opinion about Alzheimer disease among blacks, hispanics, and whites: results from a national survey. Alzheimer Dis Assoc Disord 2007, 21:232-240. 
42. Hall M, Olopade Ol: Confronting genetic testing disparities. JAMA 2005, 293:1783-1785

43. Jonassaint CR, Santos ER, Glover CM, Payne PW, Fasaye GA, Oji-Njideka N, Hooker S, Hernandez W, Foster MW, Kittles RA, Royal CD: Regional differences in awareness and attitudes regarding genetic testing for disease risk and ancestry. Hum Genet 2010, 128:249-260.

44. Deyo RA: Cascade effects of medical technology. Annu Rev Public Health 2002, 23:23-44.

45. Farran C, James B, Johnson T, Scholz K, Weuve J: 2011 Alzheimer's disease facts and figures. Alzheimers Dement 2011, 5:1-66.

46. Neumann PJ, Cohen JT, Hammitt JK, Concannon TW, Auerbach HR, Fang C, Kent DM: Willingness-to-pay for predictive tests with no immediate treatment implications: a survey of US residents. Health Econ 2012, 21:238-251.

47. Post SG, Whitehouse PJ, Binstock RH, Bird TD, Eckert SK, Farrer LA, Fleck LM, Gaines AD, Juengst ET, Karlinsky H, Miles S, Murray TH, Quaid KA, Relkin NR, Roses AD, St George-Hyslop PH, Sachs GA, Steinbock B, Truschke EF, Zinn AB: The clinical introduction of genetic testing for Alzheimer disease. An ethical perspective. JAMA 1997, 277:832-836.

48. Roberts JS, Uhlmann WR: Genetic susceptibility testing for neurodegenerative diseases: ethical and practice issues. Prog Neurobiol 2013.

49. Zick CD, Mathews CJ, Roberts JS, Cook-Deegan R, Pokorski RJ, Green RC: Genetic testing for Alzheimer's disease and its impact on insurance purchasing behavior. Health Aff (Millwood) 2005, 24:483-490.

50. Oster E, Shoulson I, Quaid K, Dorsey ER: Genetic adverse selection: evidence from long-term care insurance and Huntington disease. J Public Econ 2010, 94:1041-1050.

51. Van Hoyweghen I, Horstman K: European practices of genetic information and insurance: lessons for the Genetic Information Nondiscrimination Act. JAMA 2008, 300:326-327.

52. Oster E, Dorsey ER, Bausch J, Shinaman A, Kayson E, Oakes D, Shoulson I, Quaid K, Huntington Study Group PHAROS Investigators: Fear of health insurance loss among individuals at risk for Huntington disease. Am J Med Genet A 2008, , 146A: 2070-2077.

53. Tambor ES, Bernhardt BA, Chase GA, Faden RR, Geller G, Hofman KJ Holtzman NA: Offering cystic fibrosis carrier screening to an HMO population: factors associated with utilization. Am J Hum Genet 1994, 55:626-637.

54. Lerman C, Narod S, Schulman K, Hughes C, Gomez-Caminero A, Bonney G, Gold K, Trock B, Main D, Lynch J, Fulmore C, Snyder C, Lemon SJ, Conway T, Tonin P, Lenoir G, Lynch H: BRCA1 testing in families with hereditary breast-ovarian cancer. A prospective study of patient decision making and outcomes. JAMA 1996, 275:1885-1892.

55. Miller SM: Monitoring and blunting: validation of a questionnaire to assess styles of information seeking under threat. J Pers Soc Psychol 1987, 52:345-353.

doi:10.1186/alzrt206

Cite this article as: Wikler et al:: Would you want to know? Public attitudes on early diagnostic testing for Alzheimer's disease. Alzheimer's Research \& Therapy 2013 5:43.

\section{Submit your next manuscript to BioMed Central and take full advantage of:}

- Convenient online submission

- Thorough peer review

- No space constraints or color figure charges

- Immediate publication on acceptance

- Inclusion in PubMed, CAS, Scopus and Google Scholar

- Research which is freely available for redistribution

Submit your manuscript at www.biomedcentral.com/submit
Biomed Central 